\section{Storm success came easy}

\section{London}

THE UK Meteorological Office is this week congratulating itself for predicting successfully the hurricane-force gales which ravaged the British Isles on 25 January, leaving a trail of destruction and 47 dead. Strong winds were predicted when a deepening depression was picked up in the central Atlantic the previous weekend. When the pressure at the centre of the weather system began to plummet on the afternoon of 24 Janu-

ary, they forecast that a severe storm would hit the United Kingdom the next day, and warned that "structural damage is expected".

The Meteorological Office is keen to stress the accuracy and speed of its forecasts, following its failure to give similar warning of the storm that devastated southern England on 15-16 October 1987, claiming 19 lives. In 1987, the Meteorological Office's two forecasting models - a 'fine mesh' model, which gives detailed predic-

tions, and a 'coarse mesh' Not far from Nature's London office, a tree felled in the 25 model, which is less detailed January storm. (AP)

but is updated more often - gave different results. This time, the models agreed, says Martin Morris, head of central forecasting.

In the wake of the 1987 storm, a report commissioned by the Ministry of Defence, which funds the Meteorological Office, concluded that training was inadequate and that senior forecasters were not afforded sufficiently high status. Since then, training has been extended and career structure overhauled. Televised weather forecasts now include more explicit storm warnings, and the system of notifying the emergency services has been streamlined.

But the nature of the storm, rather than changes in the Meteorological Office, provides the main reason for the differ- ence in performance in 1987 and this year. Professor Brian Hoskins of the University of Reading explains that the 1987 storm did not have an obvious precursor in a marked depression, but was formed when several less obvious features came together. In its final approach to the English coast, the storm gained energy very rapidly as condensing rain released latent heat into the system. Morris says that the full potential of the 1987 storm

\section{IMAGE UNAVAILABLE FOR COPYRIGHT REASONS}

became apparent only a few hours before it came ashore.

This year's storm had a more leisurely and predictable development. Nevertheless, the occurrence of two hurricaneforce storms over the English mainland within the space of three years raises the question of global climate change. Hoskins says that the storms were unusual, not in their intensity, but in their location. Usually, similar storms either 'blow themselves out' over the Atlantic, or pass over sparsely populated areas in northwest Scotland. He is currently examining the influence of greenhouse warming on storms, and believes that local shifts in storm paths are a possible consequence.

Peter Aldhous

\section{Towards a $2^{\circ} \mathrm{C}$ concensus}

\section{Washington}

EARLY signs of a scientific consensus on global warming emerged last week as toplevel representatives from more than 40 countries prepared to gather in Washington next week for a meeting of the Intergovernmental Panel on Climate Change (IPCC)

Briefing a National Academy of Sciences panel on global change, a panel of atmospheric scientists agreed that significant effects from the greenhouse effect may now be considered "very probable." Although there was some disagreement on the magnitude of the expected temperature rise, almost all of the scientists briefing the academy believe mean global temperatures will go up by at least $2{ }^{\circ} \mathrm{C}$ by the middle of the next century. But the rise will not be uniform - the latest models show that the Northern Hemisphere, with a large land mass, will warm far more than the largely oceanic Southern Hemisphere.

Although the United States is not expected to announce any radical policy changes at the IPCC meeting next week, President George Bush may use the opportunity to highlight environmental features, such as a new $\$ 170$ million treeplanting initiative, in his 1991 budget, which was released earlier this week (see p. 397). The administration is already touting a $\$ 500$ million increase in global warming research funding for 1990 , but most of that rise is due more to creative accounting than new money. Real increases in 1990 amount to about $\$ 60$ million above 1989's $\$ 134$ million research budget.

The administration may have to get its own house in order before it can hope to take a leading role on international global warming policy. The US government continues to be characterized by "interagency squabbling", according to Alan Miller of the University of Maryland's Center for Global Change. But with several European countries beginning $\mathrm{CO}_{2}$ emission reduction programmes, the US administration risks falling out of step with international opinion on global warming. For that reason, President Bush has called for a White House meeting of top-level scientific and economic advisers from selected countries in the Spring. The meeting will help the Administration "determine where the uncertainties are in the science and economics of the issue", a White House spokeswoman says.

Congressional action may be on a faster track. In both the House and Senate, part of major bills to promote energy efficiency, emission controls, and reforestation are expected to pass this year.

G. Christopher Anderson

the accuracy of general-circulation-model

\section{GCM) predictions.}

climatic effects of vegetation and house gases, whilst WCRP has concentrated on the interaction between the Sun's energy and the Earth's surface, and its en water relations. Climate pre tion using GCMs requires complementary ata from all of these areas.

Major studies agreed by the IGBPWCRP committee include those on desertification in the Niger Sahel, deforestation in the Amazon basin, and of carbon cycling in the Canadian boreal forest. Peter Aldhous 